cases are novel, and to be commended. We were unable, however, to follow the proof of the selfinduction of two parallel wires forming a loop (p. 82). However, the answer given is correct, which is the main thing from the practical man's point of view. The distinctions between the capacity of a condenser, the capacity of a conductor, and the capacity between two parallel wires, are not clearly explained. In proving the formula for the latter, the assumption is made that the charges can be concentrated along the inverse lines of the two cylinders. A proof of this should have been given. As a rule, the symbols have been happily chosen. On p. 47, however, $Z$ is used to denote a current; this use we think quite inadmissible. On p. 402 it denotes impedance, a use which has international sanction.

\section{Geography and Travel.}

Antarctica : a Treatise on the Southern Continent. By J. Gordon Hayes. Pp. xv $+448+16$ plates. (London: The Richards Press, Ltd., 1928.) $42 s$. THe knowledge of Antarctic matters has grown at so great a rate during the twentieth century, owing to the intensive scientific exploration of several areas, that a comprehensive work bringing together in one volume the results achieved cannot fail to be of value. This is part of the task that Mr. Gordon Hayes has set himself. In addition, he gives a critical estimate of the value of recent expeditions, and attempts some forecast of profitable lines of discovery. Beyond all this there are a number of appendices, a bibliography, many excellent illustrations, and a few maps.

There can be no doubt that Mr. Gordon Hayes has brought industry and enthusiasm to his task; and though he has no personal experience of polar work, he has at least the advantage of being an impartial critic of all expeditions. Yet it must be admitted that the book has several omissions and not a few inaccuracies, and falls far short of being a treatise on Antarctica. Some of his criticisms, such as of transport by man-haulage, are of value, but his strictures of the Wilkes expedition are somewhat severe, and his basis for judging the success of an expedition by the length of coast-line discovered is most unscientific. His list of casualties, which he calls the Antarctic Roll of Honour, is incomplete.

It is on the scientific side, however, as apart from the record of discovery, that the book falls far short of its author's aim. This is not surprising when it is realised from the author's list of works consulted that his material is derived mainly from the popular narratives of expeditions. These are not designed to give the scientific results. They are for popular reading. Of the many volumes of scientific reports of recent expeditions, practically the only ones mentioned are those of the Terra Nova and a few papers on the work of the Endurance. Moreover, there is almost entire omission of French and German works even of a popular nature. If Mr. Gordon Hayes does not make use of the available sources of material, he cannot claim to have written an authoritative treatise.
The People of Tibet. By Sir Charles Bell. Pp. xix $+319+57$ plates. (Oxford: Clarendon Press; London: Oxford University Press, 1928.) $21 s$. net.

Sir Charles Bell has written a most interesting and very well illustrated book on the mode of life and domestic customs of the Tibetans which may be accepted as authoritative. The shepherds and herdsmen are probably the purest specimens of the race. The inclement conditions, especially hailstorms, render the peasants' life a hard one. There is a great gulf between these classes and the nobility: the trading community forms a middle class, but with little power; the foreign trade is in their hands, and even the nobility have their commercial agents, for the Tibetan is a born trader. Begging is a hereditary profession, but the monks who go a-begging are on a different footing. There are few countries where women have so good a position, and they are active and shrewd in business matters. Monogamy, polygyny, and polyandry are all found in Tibet, but on the whole monogamy is more prevalent.

The daily life of the gentry is permeated with ceremonial and etiquette, and the usages of courtesy in all its branches are carefully taught to the young. Many of the troubles of travellers here and elsewhere have been due to non-observance of etiquette. Tibet does not lack land fit for cultivation, but lacks the men to till it. The population is decreasing owing to various causes, perhaps more especially to the large number that live celibate lives in monasteries instead of rearing families.

\section{Geology and Mineralogy.}

Kohlenpetrographisches Praktikum. Von Dr. Erich Stach. (Sammlung naturwissenschaftlicher Praktika, Band 14.) Pp. iv + 196. (Berlin: Gebrüder Borntraeger, 1928.) $\quad 10 \cdot 80$ gold marks.

DURING the last twenty years great progress has been made in the study of coal. Instead of treating it only as a material which on combustion gave certain products, investigators have been studying the material itself, its constituents, their mode of occurrence and association, and their probable method of origin. Coal is a rock rather than a mineral, and much of the progress that has been made has come from its examination by petrological methods. These methods have been developed independently in England, America, and Germany, and their results have been described in many widely scattered publications, consequently a brief summary of the work with a full list of references is very valuable.

The present work is probably more valuable as a survey of the field than as a practical handbook. In the preparation of coal specimens for microscopical examination there are so many technical difficulties and so many ' tricks of the trade' that it is doubtful whether anyone could be sure of success by simply following descriptions of the methods employed. But after describing methods, the author gives a brief but impartial statement of some of the results achieved, illustrated with many 